\title{
Distribution of biologically labelled radioactive hyaluronic acid injected into joints
}

\author{
K. N. ANTONAS, J. R. E. FRASER, AND K. D. MUIRDEN \\ From the University of Melbourne Department of Medicine, The Royal Melbourne Hospital, \\ Victoria, Australia
}

Hyaluronic acid is synthesized in the tissues where it is found, a fact which has been amply demonstrated by culture of the appropriate cells in vitro (Vaubel, 1933; Kling, Levine, and Wise, 1955; Grossfeld, Meyer, Godman, and Linker, 1957). The synthetic sequences have also been intensively studied. However, knowledge of the extracellular movement of hyaluronic acid is fragmentary by comparison, although the distribution of tissue hyaluronidases indicates potential sites of breakdown (Bollet, Bonner, and Nance, 1963; Vaes and Jacques, 1965).

The widespread distribution of hyaluronic acid virtually requires a radioactive marker to trace its movements. The choice of isotope is limited by the need to incorporate it by covalent bonding, which means at the present time the use of ${ }^{14} \mathrm{C}$ - or ${ }^{3} \mathrm{H}$ labelled glucose or glucosamine as a substrate in the initial synthesis of the hyaluronic acid. The low intensity of radiation from these isotopes precludes the use of external counters for tracing, but on the other hand lessens the risk of degradation of the polymer by autoirradiation during a long preparation and storage.

After the choice of substrate, there are two possible courses. The substrate can be administered to provide an estimate of the subsequent turnover of the glycosaminoglycans and their intermediates extracted at intervals thereafter (See, for example, Schiller, Slover, and Dorfman, 1962; Hardingham and Phelps, 1968). This is complicated by the potential incorporation of the substrate in other macromolecules. Alternatively, mammalian cell cultures can be used to synthesize hyaluronic acid from isotopic substrates (Yielding, Tomkins, and Bunim, 1957) and the largest polymers selected and purified by gel chromatography (Baxter, Fraser, and Harris, 1973) before study in vivo.

This paper describes development of the latter approach to study the fate of hyaluronic acid within synovial joints.

\section{Methods}

PREPARATION OF HYALURONIC ACID

(i) Biosynthesis and isolation The methods used have been fully described elsewhere (Baxter and others, 1973). To increase the radioactivity, the synovial cell culture media contained up to $17 \mu \mathrm{c}$. of ${ }^{14} \mathrm{C}(\mathrm{U})$-D-glucose per ml. Larger gel chromatography columns were used to take larger samples, and the final separation was performed with Sepharose 2B (Pharmacia).

(ii) Sterilization The solution of radioactive hyaluronic acid in $0.15 \mathrm{M} \mathrm{NaCl}$ was placed in sterile capped $10-\mathrm{ml}$. polypropylene tubes with penicillin $G$, streptomycin, and neomycin added to levels of 100 units or $100 \mu \mathrm{g}$. respectively. A control solution of $0.15 \mathrm{M} \mathrm{NaCl}$ with antibiotics was also prepared. Both solutions were subjected to $30,000 \mathrm{G}$. in a Sorvall RCB2 centrifuge for $1 \mathrm{hr}$ and allowed to come to rest without braking. The uppermost $4 \mathrm{ml}$. of each solution were carefully transferred to sterile sealed vials, and the remainder deep-frozen for reprocessing. Sterility was confirmed by at least 72 hrs' culture, anaerobically in Robertson's cooked meat medium and aerobically in serum broth and blood agar plates.*

Absence of degradation was confirmed by chromatography in Sepharose 2B with serum proteins as markers.

\section{INJECTION OF SYNOVIAL JOINTS}

Adult albino New Zealand rabbits weighing about $2 \mathrm{~kg}$. were anaesthetized with intravenous sodium thiopentone. 1-2 ml. of the solutions of radioactive hyaluronic acid containing 90,000 to 300,000 counts per minute (see below) were injected into the right knee joint through the patellar ligament. The control saline solution was injected into the left knee joint. Aqueous Evans blue B.P. was injected into the skin of each foot to help locate lymph nodes later. On recovery, the rabbits were allowed free movement in a large cage.

\section{PREPARATION OF TISSUE SAMPLES}

After the animals had been killed with an overdose of sodium thiopentone, the left side was first dissected. The

* Courtesy of Miss M. Presser, B.Sc. 
synovial cavity of the knee was opened laterally, and any free fluid removed before thorough irrigation of the joint with saline. Tissues were removed in the following order: popliteal lymph node (by separate access), thigh muscle, meniscus, synovium, and finally, articular cartilage in slivers down to underlying bone. A fresh scalpel blade was used for each tissue. The right side was dissected in the same sequence with a separate set of instruments. The samples were trimmed free of any fat, placed immediately in separate Petri dishes and washed vigorously in saline. After blotting, portions were placed in fixative, or in weighed bottles for digestion.

\section{AUTORADIOGRAPHY AND HISTOLOGY}

The washed specimens were fixed at room temperature for $24 \mathrm{hrs}$ in 10 per cent. formalin, $\mathrm{pH} 7.2$ in $0.05 \mathrm{M}$ phosphate buffer with 0.5 per cent. cetyl trimethylammonium bromide (Józsa and Szederkényi, 1967). The specimens were then washed in water, taken stepwise to 100 per cent. ethanol, and blocked in paraffin wax. Sections were cut at $7 \mu$., placed on gelatinized slides, and dewaxed in two changes of xylene and two of dioxane, overnight in each case. This eliminated artefacts from traces of wax. The slides were then taken through to water and washed overnight. After draining, the slides were dipped for 1-2 sec. in Kodak NTB2 emulsion warmed to $40^{\circ} \mathrm{C}$., drained again, hung overnight in a lightproof dessicator, and exposed at $2^{\circ} \mathrm{C}$. for 1-12 weeks in sealed Clay Adams boxes with dessicant. Emulsion was developed in Kodak D19B, fixed, and rinsed. The sections were stained in Unna-Pappenheim, mounted in polystyrene, and examined systematically with bright field optics, oil immersion, and darkground illumination.

TISSUE DIGESTION

Aliquots of the washed and blotted tissue (ranging from 17 to $640 \mathrm{mg}$.) were digested with $0.5 \mathrm{ml}$. Pronase solution at $60^{\circ} \mathrm{C}$. for $48-72 \mathrm{hrs}$ to achieve full dispersion. The

* Courtesy of Dr. B. J. Clarris solution contained $5 \mathrm{mg}$. enzyme (Pronase AS, 15,000 p.k.u. per g., Kaken Chemical Co., Japan) per ml. phosphate-buffered saline, $\mathrm{pH} \mathbf{7 \cdot 2}$.

\section{SCINTILLATION COUNTING}

Aliquots of the digests and of plasma $(0.2 \mathrm{ml}$.) were dissolved in $0.5 \mathrm{ml}$. Hyamine $10 \mathrm{X}$ and mixed with $10 \mathrm{ml}$. toluene-based scintillation fluid containing Triton X100, 16 parts to 3 respectively. 20-minute counts were made in a Packard Model 3380 Scintillation Counter.*

\section{Results}

The knee joints accommodated 1-2 ml. without firm distension. The injected fluid was rapidly absorbed: frankly excessive free fluid was found once, at $24 \mathrm{hrs}$. Bacterial cultures of this fluid and from swabs of other injected joints were all sterile. Haemorrhagic staining occurred in two joints injected with the control iv solution. The others presented a macroscopically $\overrightarrow{0}$ normal, glistening wet synovial lining, from which a $\omega$ little viscous fluid was aspirated in two instances. No microscopic evidence of inflammation was found in the excised tissues of the joints.

\section{A UTORADIOGRAPHY}

Tissues from the control limbs were used to recognize precipitation of silver grains due to structura artefacts and to gauge the level of background precis pitation (Figs 1 and 2), which varied with differe batches of emulsion. The commonest artefact was linear precipitation between retracted bundles of muscle fibres or fibrous tissue.

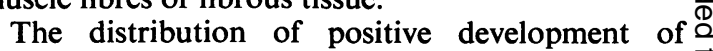
emulsion is shown in Tables I and II. None was seen $\overrightarrow{\overrightarrow{0}}$ within the structures of the joint under 2 to $6 \mathrm{hrs}$, or 3 on their inner surfaces, which demonstrated that

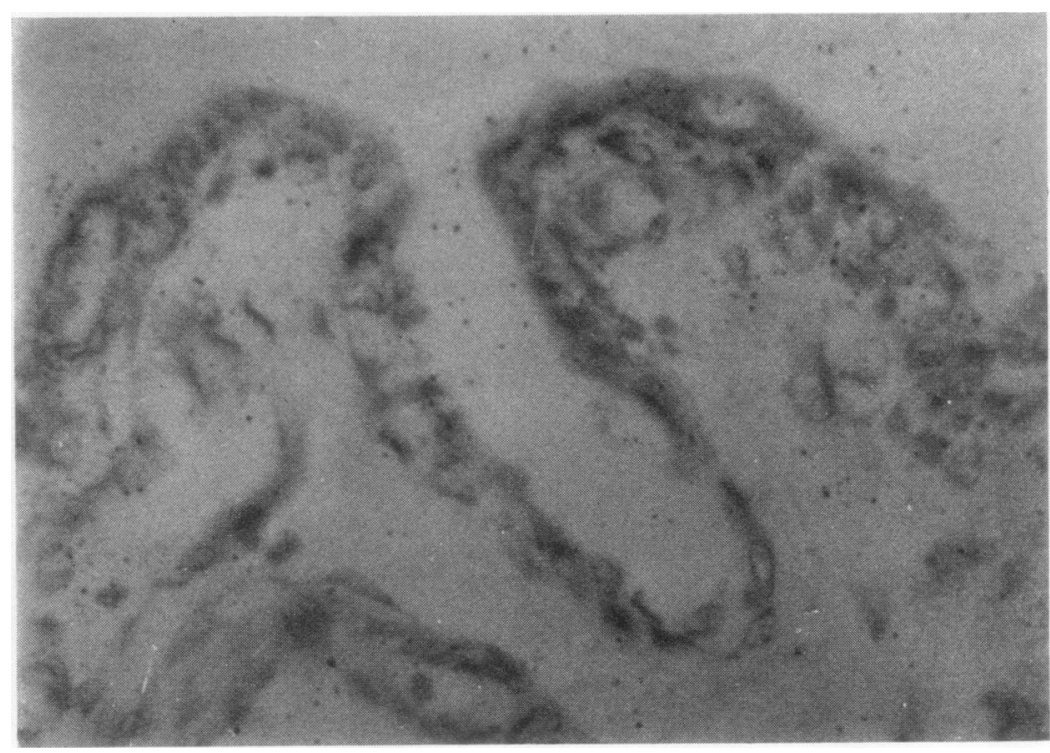

FIG. 1 Control injection. Synovial folds, showing random $\mathrm{N}$ scattering of silver grains. $\times 115 \mathrm{~N}$ 


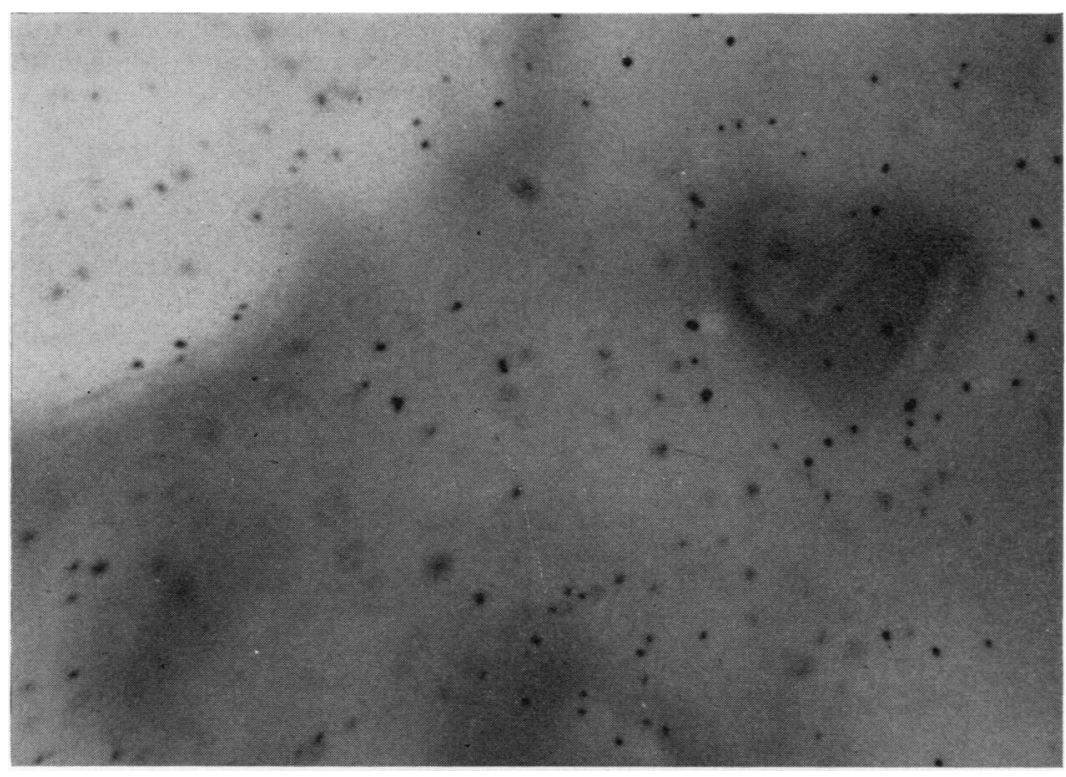

FIG. 2 Control injection. Articular cartilage, showing random background scattering of silver grains. $\times 370$

Table I Autoradiography, first series

\begin{tabular}{|c|c|c|c|c|c|c|}
\hline \multirow{2}{*}{$\begin{array}{l}\text { Experiment } \\
\text { no. }\end{array}$} & \multirow[t]{2}{*}{ Duration } & \multicolumn{5}{|l|}{ Tissues } \\
\hline & & Synovium & Meniscus & $\begin{array}{l}\text { Articular } \\
\text { cartilage }\end{array}$ & $\begin{array}{l}\text { Popliteal } \\
\text { lymph node }\end{array}$ & Muscle \\
\hline $\begin{array}{l}1 \\
2 \\
3 \\
4 \\
5 \\
6 \\
7\end{array}$ & $\begin{array}{c}15 \mathrm{~min} . \\
1 \mathrm{hr} \\
2 \mathrm{hrs} \\
6 \mathrm{hrs} \\
24 \mathrm{hrs} \\
48 \mathrm{hrs} \\
7 \text { days }\end{array}$ & $\begin{array}{l}0 \\
\text { Trace } \\
+ \\
+ \\
+ \\
+ \\
0\end{array}$ & $\begin{array}{l}0 \\
\text { Trace } \\
0 \\
0 \\
+ \\
+ \\
0\end{array}$ & $\begin{array}{l}0 \\
0 \\
0 \\
+ \\
+ \\
+ \\
+\end{array}$ & $\begin{array}{l}+ \\
+ \\
0 \\
+ \\
0 \\
0 \\
0\end{array}$ & $\begin{array}{l}0 \\
0 \\
0 \\
0 \\
0 \\
0 \\
0\end{array}$ \\
\hline
\end{tabular}

+ indicates positive development of emulsion over tissue. See text.

Table II Autoradiography, second series, with scintillation counts

\begin{tabular}{|c|c|c|c|c|c|c|c|c|c|c|c|c|}
\hline \multirow{2}{*}{$\begin{array}{l}\text { Experiment } \\
\text { no. }\end{array}$} & \multirow{2}{*}{$\begin{array}{l}\text { Duration } \\
\text { (hrs) }\end{array}$} & \multicolumn{6}{|c|}{ Right knee } & \multicolumn{5}{|c|}{ Left knee (control) } \\
\hline & & & ynovium & Meniscus & $\begin{array}{l}\text { Articular } \\
\text { cartilage }\end{array}$ & $\begin{array}{l}\text { Popliteal } \\
\text { lymph } \\
\text { node }\end{array}$ & Muscle & Synovium & Meniscus & $\begin{array}{l}\text { Articular } \\
\text { cartilage }\end{array}$ & $\begin{array}{l}\text { Popliteal } \\
\text { lymph } \\
\text { node }\end{array}$ & Muscle \\
\hline 8 & 8 & $\begin{array}{l}\mathbf{a} \\
\mathbf{b}\end{array}$ & $\begin{array}{c}3.9 * \\
+\end{array}$ & $\begin{array}{l}1 \cdot 1^{*} \\
+\end{array}$ & $\begin{array}{l}0.4 \\
+\end{array}$ & $\begin{array}{c}4 \cdot 9^{*} \\
+\end{array}$ & $\begin{array}{l}\text { N.D. } \\
\text { N.D. }\end{array}$ & 0.4 & $0 \cdot 1$ & $0 \cdot 1$ & 0.0 & N.D. \\
\hline 9 & 11 & $\begin{array}{l}\mathbf{a} \\
\mathbf{b}\end{array}$ & $\begin{array}{c}13 \cdot 6^{*} \\
+\end{array}$ & $\begin{array}{c}2 \cdot 1^{*} \\
?\end{array}$ & $\begin{array}{c}2 \cdot 9^{*} \\
+\end{array}$ & $\begin{array}{r}0.2 \\
0\end{array}$ & $\begin{array}{c}0.6 \\
0\end{array}$ & $0 \cdot 1$ & 0.2 & 0.7 & 0.5 & $0 \cdot 2$ \\
\hline 10 & 24 & $\begin{array}{l}a \\
b\end{array}$ & $\begin{array}{l}3 \cdot 0^{*} \\
+\end{array}$ & $\begin{array}{c}0.7 \\
0\end{array}$ & $\begin{array}{c}2 \cdot 2^{*} \\
+\end{array}$ & $\begin{array}{c}\text { N.D. } \\
0\end{array}$ & $\begin{array}{c}0.01 \\
0\end{array}$ & 0.0 & 0.1 & 0.0 & N.D. & 0.0 \\
\hline 11 & 24 & $\begin{array}{l}\mathrm{a} \\
\mathrm{b}\end{array}$ & $\begin{array}{l}8.9^{*} \\
+\end{array}$ & $\begin{array}{r}0.5 \\
+\end{array}$ & $\begin{array}{c}2 \cdot 6^{*} \\
+\end{array}$ & $\begin{array}{c}6 \cdot 0^{*} \\
?\end{array}$ & $\begin{array}{r}0.3 \\
0\end{array}$ & 0.1 & 0.0 & 0.0 & 0.1 & $0 \cdot 1$ \\
\hline 12 & 48 & $\begin{array}{l}\mathbf{a} \\
\mathbf{b}\end{array}$ & $\begin{array}{c}10 \cdot 5^{*} \\
+\end{array}$ & $\begin{array}{c}1 \cdot 2^{*} \\
+\end{array}$ & $\begin{array}{c}2 \cdot 4^{*} \\
+\end{array}$ & $\begin{array}{r}0 \cdot 3 \\
0\end{array}$ & $\begin{array}{r}0 \cdot 1 \\
0\end{array}$ & 0.4 & $0 \cdot 1$ & 0.3 & 0.2 & 0.0 \\
\hline
\end{tabular}


unabsorbed hyaluronic acid was effectively removed during preparation. Thereafter, grains were seen in the superficial cellular layer of the synovium (Fig. 3) as late as $48 \mathrm{hrs}$, but not at 7 days.

In the menisci, the activity was almost entirely restricted to the cellular synovial lining in both tangential and vertical sections. A little linear deposition in the interfibrillar matrix at $48 \mathrm{hrs}$ was considered to be a probable structural artefact (Fig. 4).

In the articular cartilage, grains were most numerous in the vicinity of the chondrocytes both within and around the lacunae. The activity was mainly in the superficial and middle zones of the cartilage, but within these areas there was considerable variation from cell to cell (Figs 5 and 6, opposite.)
Activity in the popliteal lymph nodes occurred mainly in the peripheral sinuses and adjacent cells (Figs 7 and 8, overleaf), but was not so consistently detected.

\section{SCINTILLATION COUNTING OF TISSUE \\ DIGESTS}

The second series of studies included autoradiography performed in parallel with scintillation counting of tissue digests (Table II). The mean background counting rate of reagent blanks was 15.3 counts per min. (S.D. 1.6 ; range $13.6-18.6 ; N=7$ ); that of digested tissues of an untreated rabbit was $15 \cdot 3$ counts per min. (S.D. $=1.3$; range $13 \cdot 0-18 \cdot 2$;

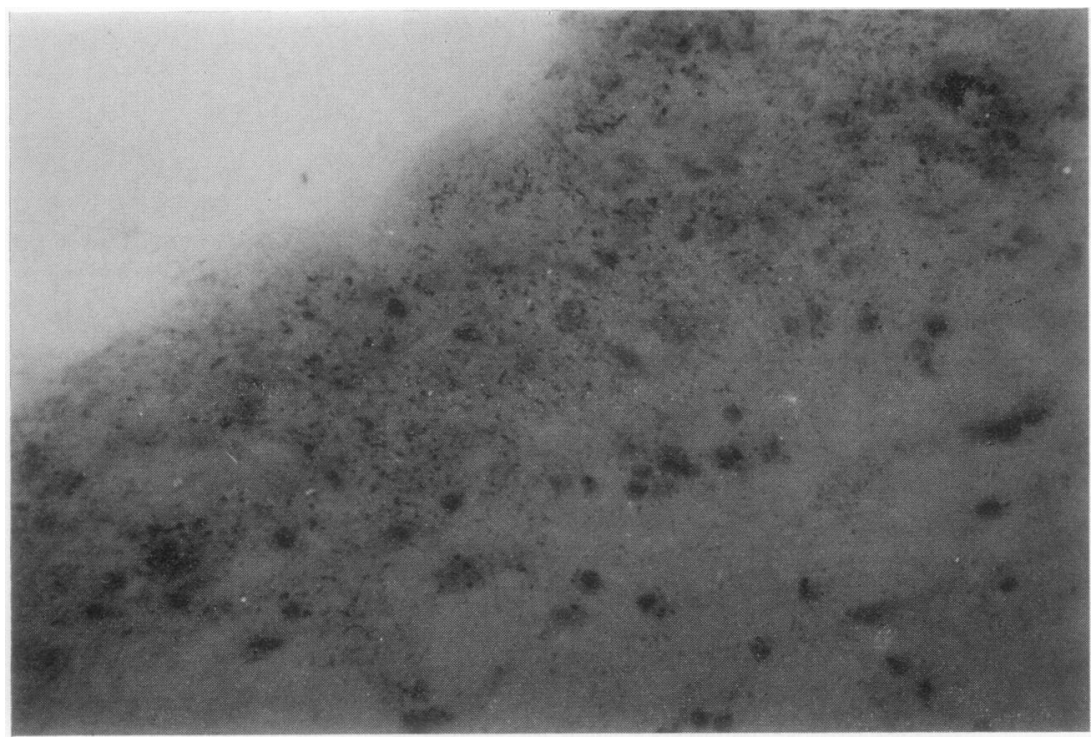

FIG. $3{ }^{14} C$-hyaluronic acid injection. Synovium, showing extent of activity over super? ficial layers at $24 \mathrm{hrs} . \times 115$

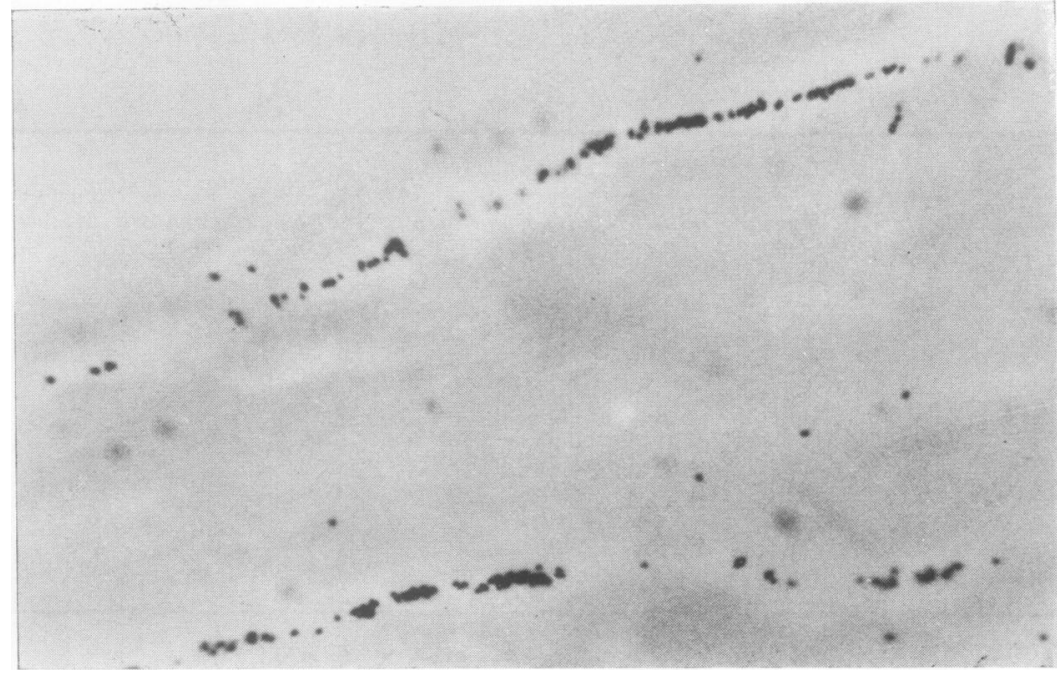

FIG. 4 Control injection. Fibrocartilage of meniscus. Dense linear deposition of silver grains considered to be possible artefacts in fissures. $\times 115$ 


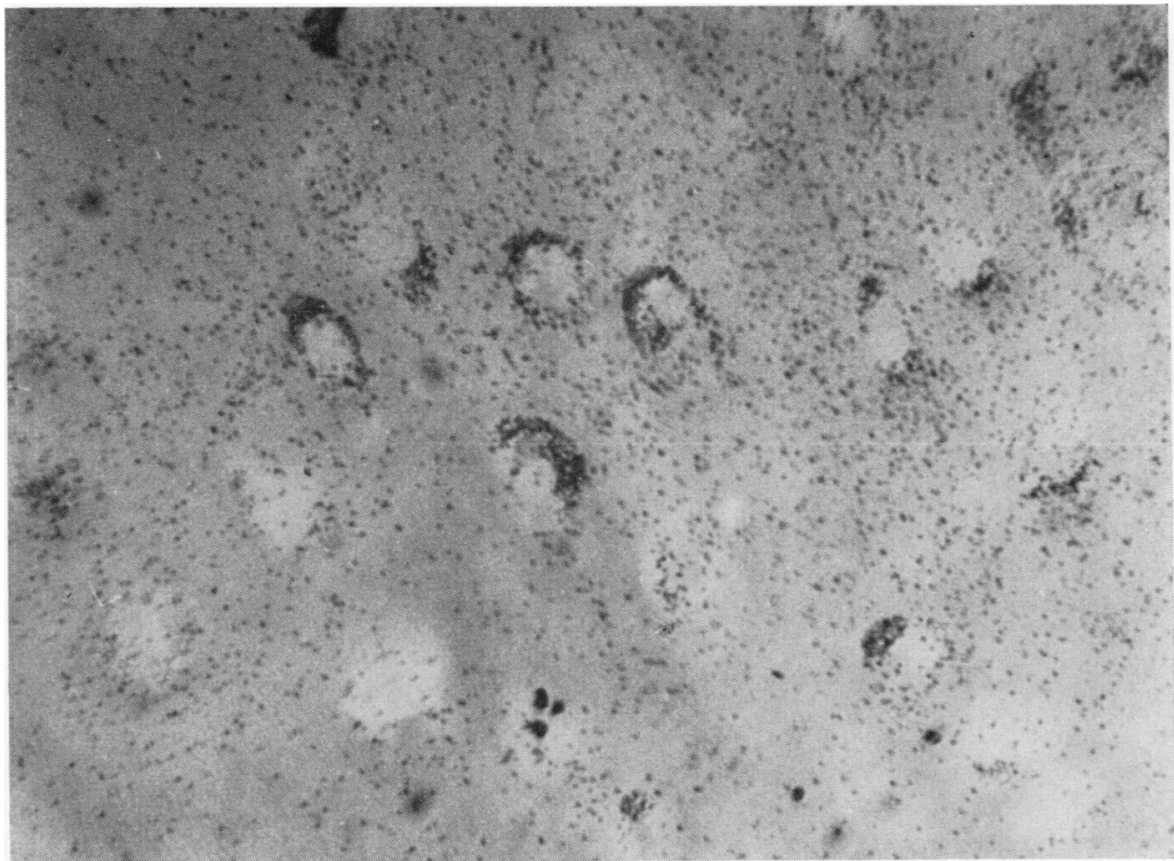

FIG. $5{ }^{14}$ C-hyaluronic acid injection. Articular cartilage in middle and deeper zones, showing variable development round chondrocytes. 9 hrs. $\times 115$

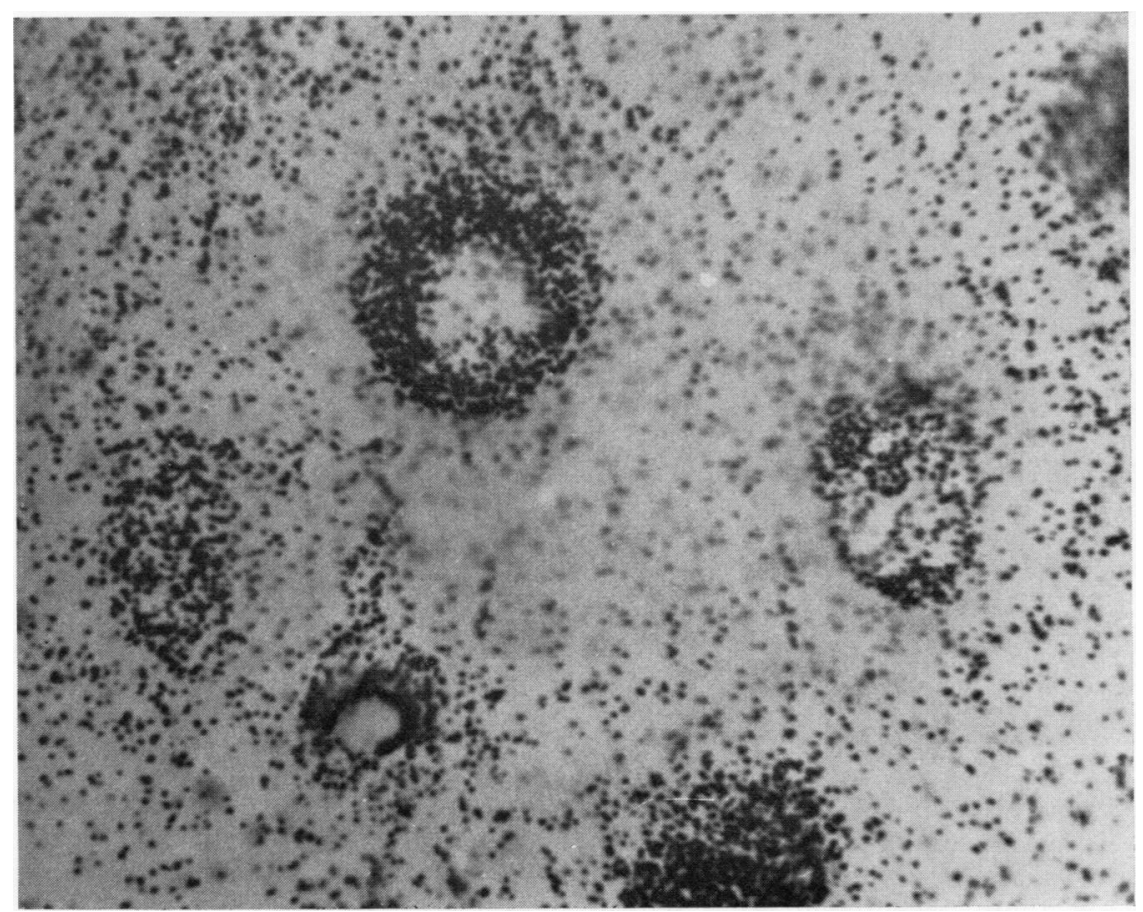

FIG. $6{ }^{14}$ C-hyaluronic acid injection. Articular cartilage, showing activity concentrated in and around lacunae of chondrocytes in the mid-zone. Some of the concentrations of grains (left and lower edges) do not clearly show lacunae and may be tangential to cells not included in the section. 6 hrs. $\times 370$ 


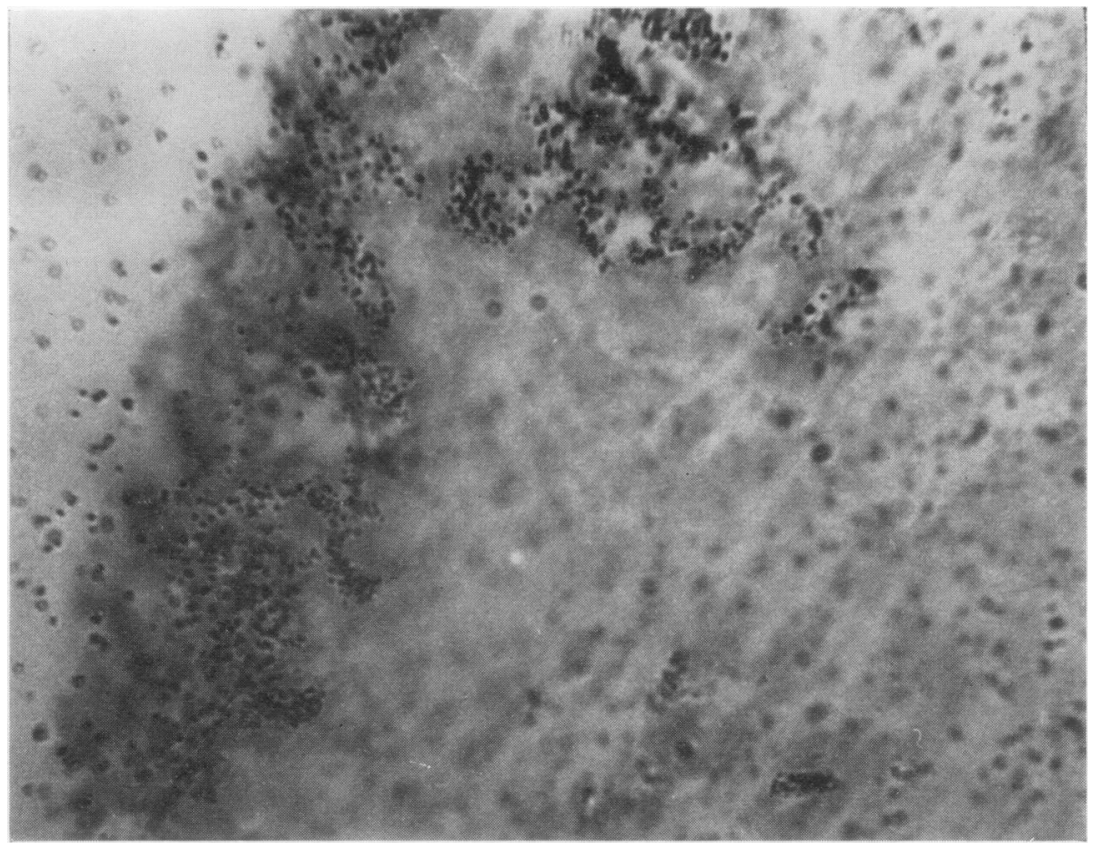

FIG. $7{ }^{14} C$-hyaluronic acid के injection. Popliteal lymph $\vec{\circ}$ node, showing localized activity in periphery. 9 hrs. $\times 115$

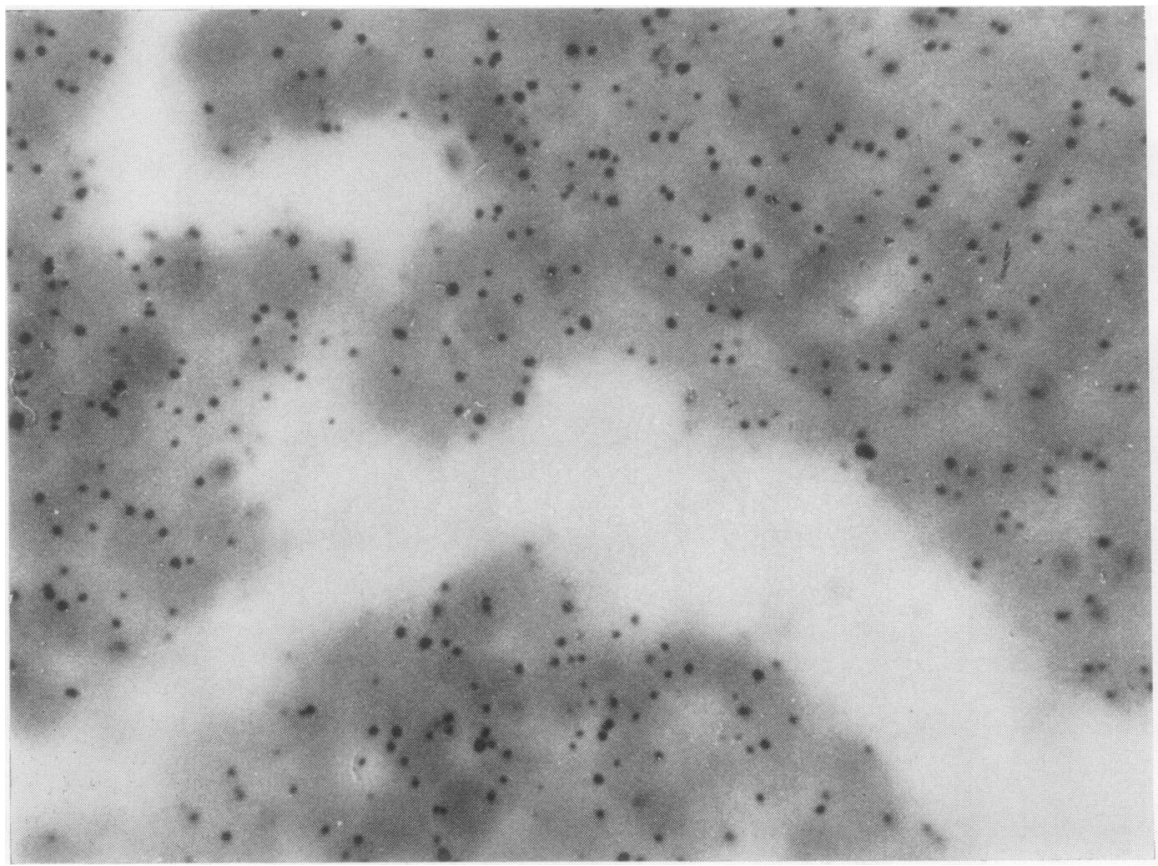

FIG. $8{ }^{14} C$-hyaluronic acid injection. Sinus region in popliteal lymph node. Grains developed 3 . over adjacent cells. $11 \dot{\text { के }}$ hrs. $\times 370$

$N=12$ ). The figures given in the Table are expressed in terms of wet tissue weight. Those marked with an asterisk represent samples in which the actual count was significantly above background. They remain clearly distinct after the correction for tissue weight.

The two methods of detecting radioactivity agreed in all samples of synovium and articular cartilage.
The discrepancies in the samples of meniscus were? considered to be due to variations in the amount of $\underline{T}$ synovial intima attached to the fibrocartilage. For $\stackrel{\vec{D}}{\vec{D}}$

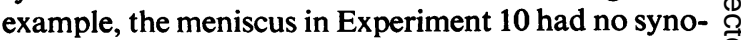
vial intima in the sections examined by autoradio- $\mathbb{Q}$ graphy.

In the case of the popliteal lymph nodes, relatively 
high levels of radioactivity were found at 8 and $24 \mathrm{hrs}$, but not at $11 \mathrm{hrs}$ or in a second study at $24 \mathrm{hrs}$. The popliteal node in the rabbit is a large, seemingly single, structure and, since it was not always evenly stained by the injection of dye, it might possess macroscopically unrecognised divisions that drain different parts of the limb and so produce sampling variations. Other tissues examined were bone marrow, heart muscle, liver, spleen, kidney, and ear cartilage. Only the ear cartilage showed a significant degree of activity: 0.90 counts per min. at $48 \mathrm{hrs}$.

Two samples of viscous joint fluid were aspirated without dilution in Experiments 9 and 10. These weighed 10 and $115 \mathrm{mg}$., and contained 1,759 and 9,257 counts per min. respectively.

\section{RADIOACTIVITY IN BLOOD AFTER}

INTRA-ARTICULAR INJECTION

In two rabbits, plasma samples prepared at 4-hr intervals showed significant levels of 195 and 165 counts per min. per ml. at 8 and 12 hrs. In a third (Experiment 8), more frequent sampling showed an earlier and much higher rise in plasma radioactivity (Fig. 9).

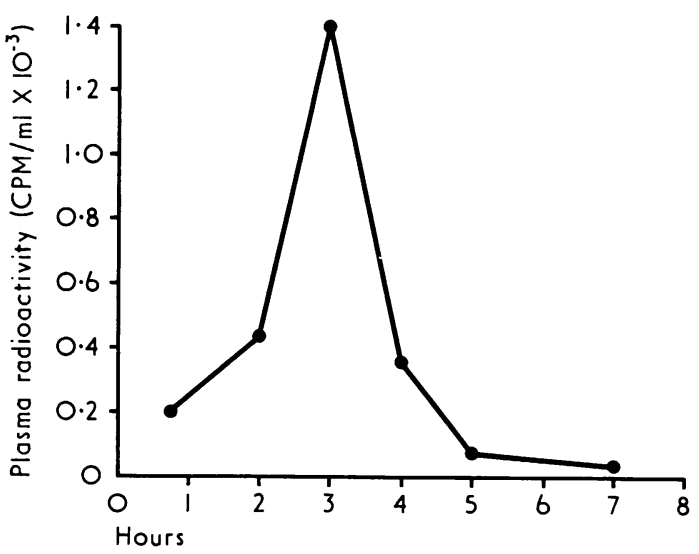

FIG. 9 Radioactivity in plasma after intra-articular injection of ${ }^{14} C$-hyaluronic acid.

Ordinate: counts/min./ml.plasma.

DISTRIBUTION OF RADIOACTIVE HYALURONIC ACID IN BLOOD STREAM

In three rabbits, radioactive hyaluronic acid was injected into a marginal ear vein, and blood samples were taken from the veins of the other ear. In one, the first sample taken at $\mathbf{2 5} \mathrm{min}$. clearly missed the early fall in plasma radioactivity. In the second, the venesection in the early stage was too slow. The results from the third are shown in Fig. 10.

To determine whether the rapid drop was due to adsorption on erythrocytes, $1 \mathrm{ml}$. radioactive hyaluronic acid containing 241,000 counts per min. was added to $10 \mathrm{ml}$. rabbit whole blood (20 units

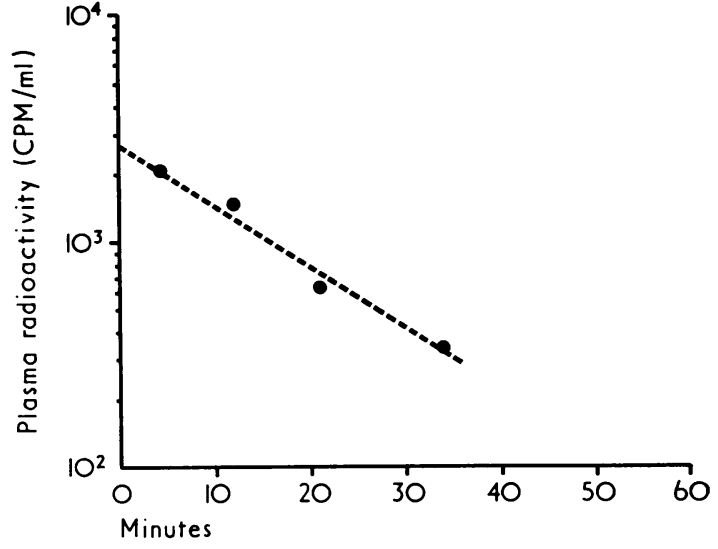

FIG. 10 Disappearance of ${ }^{14} C$-hyaluronic acid from plasma after intravenous injection.

Ordinate (y): counts/min./ml.plasma

$\log y=3.4141-0.0267 t ; r=-0.994$

Injected dose 240,000 counts/min. $y$ at $t_{0}=2,600$ counts/ min./ml.

heparin per $\mathrm{ml}$.) and to $10 \mathrm{ml}$. plasma from the same blood sample. These were incubated at $37^{\circ} \mathrm{C}$. in 5 per cent. $\mathrm{CO}_{2}$ in air, and samples taken from each up to $3 \mathrm{hrs}$. There was no fall in radioactivity in plasma prepared from the whole blood in this period. The mean recovery in plasma from the whole blood was 38,975; and in the direct mixture of plasma and hyaluronic acid, 25,200 counts per min. This indicated that the hyaluronic acid was excluded from 35 per cent. of the volume of the blood* which compared with a direct haematocrit reading of 32 per cent. Even with a generous allowance for error, adsorption on erythrocytes could not explain the rapid clearance of hyaluronic acid from plasma.

\section{Discussion}

Radioactive hyaluronic acid appeared to penetrate both lining tissues of the joint quite rapidly: the synovial intima within $2 \mathrm{hrs}$, and articular cartilage within 6 hrs.

Since the stroma of the synovial intima is a relatively open structure compared with that of cartilage, it might be permeated rather readily with changing pressures in the joint. Small molecules and even protein (Bywaters and Dorling, 1970) can also diffuse through cartilage with some facility. The principles governing this diffusion have been enunciated by Maroudas, Bullough, Swanson, and Freeman (1968). The high transient pressures imposed upon weightbearing cartilage cannot be expected to increase the rate of permeation, which is determined inter alia by the diffusion coefficient. Since this in turn is reflected

$$
\text { *i.e. } 100\left(1-\frac{25,200}{38,975}\right)
$$


in viscosity, highly polymerized hyaluronic acid seems unlikely to penetrate far into cartilage without prior degradation. The rapid transit of radioactive hyaluronic acid into cartilage, lymphatic system, and bloodstream all indicate previous degradation. A little hyaluronidase occurs in synovial fluid, and apparently in synovial tissue (Bollet and others, 1963), and synovial cells subject to lysosomal stimulation can rapidly diminish the viscosity of hyaluronic acid (unpublished observations). It is possible that the changes observed in these studies were accelerated by the injection and sudden flux of water and electrolytes in the joint, but since there was no inflammation the pattern is likely to be the same in normal circumstances.

The retention of radioactivity within the cartilage with an aqueous fixative suggests that it is in a polymerized form rather than oligosaccharide. The vicinity of the chondrocyte is an area of intense metabolic activity with degradation and synthesis of glycosaminoglycan (Collins and McElligott, 1960; Collins and Meachim, 1961) and collagen (Repo and Mitchell, 1971). The persistence of the radio-activity in cartilage raises the possibility of resynthesis of degraded hyaluronic acid and it is noteworthy that the autoradiographic patterns seen in this study are similar to those found when cartilage is exposed to proline (Repo and Mitchell, 1971) or to ${ }^{35} \mathrm{SO}_{4}$, which it incorporates in glycosaminoglycan (Dziewiatkowski, 1951).

However, the paucity of grains within the cartilage cells, and the intensity of radioactivity in or close to their periphery (Figs 5 and 6), indicates either a very rapid transit through the cells if resynthesis occurs, or co-precipitation with the macromolecular constituents in the immediate vicinity during fixation. The material in which the radioactivity of hyaluronic acid is incorporated in cartilage should therefore be extracted and identified. Similar information is also desirable to define the form in which it enters the blood stream and is distributed elsewhere in the body.

If hyaluronic acid injected through the joint enters the blood stream in a degraded form, it may be handled differently from hyaluronic acid injected direct into the blood stream. In either case, clearance from the blood is remarkably rapid. The results of injecting radioactive hyaluronic acid direct into the blood stream and of incubating it with whole blood in vitro are similar to those obtained in a much more extensive study done by Kaplan and Meyer (1962) with larger amounts of non-radioactive sulphated glycosaminoglycan in man and dog. No break-down of chondroitin sulphates $A$ and $B$ occurred in citrated whole blood after $4 \mathrm{hrs}$ at $37^{\circ} \mathrm{C}$. The half-lives of chondroitin sulphates $\mathrm{A}, \mathrm{B}$, and $\mathrm{C}$ can be estimated from their graphs to be about 60,20 , and $40 \mathrm{~min}$. respectively. The more rapid clearance of chondroitin sulphate B from the blood stream was associated with direct urinary excretion of that material which Kaplan and Meyer related to its lower molecular weight. The deproteinated chondroitin sulphates that they used would have had a much lower molecular weight than the hyaluronic acid in this study. The faster disappearance of the latter might be explained by difference in species or rate of tissue absorption.

The present study has been primarily one of feasibility. Much more active preparations of hyaluronic acid will be needed to provide adequate levels for extraction from the tissues, with improved techniques for rapid blood sampling and monitoring. For future studies, tritium might be better for finer autoradio graphic resolution.

\section{Summary}

Radioactive hyaluronic acid was purified from the culture medium of synovial cells exposed to ${ }^{14} \mathrm{C}$ labelled glucose. After injection of this material into rabbits' knee joints, radioactivity was detected by autoradiography or scintillation counting within the synovial layer, the articular cartilage, the regional lymph nodes, and blood plasma. Initial clearance of radioactivity from plasma was rapid after intraarticular or intravenous injection.

We are grateful to Mrs. Judy Mitchell and Dr. C. J. Louis for advice on autoradiography, and to Messrs. K. Rogers and D. Rowe for technical assistance. This work was supported by a grant from the National Health \& Medical Research Council of Australia.

\section{References}

Baxter, E., Fraser, J. R. E., ANd HARris, G. S. (1973) Ann. rheum. Dis., 32, 35 (Fractionation and recovery of secretions of synovial cells synthesized in culture with radioactive precursors)

Bollet, A. J., Bonner, W. M., AND NANCE, J. L. (1963) J. biol. Chem. 238, 3522 (The presence of hyaluronidase in various mammalian tissues)

Bywaters, E. G. L., AND Dorling, J. (1970) Ann. rheum. Dis., 29, 294 (Amyloid deposits in articular cartilage)

Collins, D. H., AND McElligotT, T. F. (1960) Ibid., 19, 318 (Sulphate $\left({ }^{35} \mathrm{SO}_{4}\right)$ uptake by chondrocytes in relation to histological changes in osteoarthritic human articular cartilage)

- - AND MEACHIM, G. (1961) Ibid., 20, 117 (Sulphate $\left({ }^{35} \mathrm{SO}_{4}\right)$ fixation by human articular cartilage compared in the knee and shoulder joints)

DzIEwiatkowski, D. D. (1951) J. biol. Chem., 189, 187 (Isolation of chondroitin sulfate-S ${ }^{35}$ from articular cartilage of rats) 
Grossfeld, H., Meyer, K., Godman, G., ANd Linker, A. (1957) J. biophys. biochem. Cytol., 3, 391 (Mucopolysaccharides produced in tissue culture)

Hardingham, T. E., AND Phelps, C. F. (1968) Biochem. J., 108, 9 (The tissue content and turnover rates of intermediates in the biosynthesis of glycosaminoglycans in young rat skin)

Józsa, L., AND SZEDERKÉNYI, Gy. (1967) Acta histochem., 26, 255 (Über Verluste der Gewebsmukopolysaccharide während der Fixierung)

KAPLAN, D., AND MEYER, K. (1962) J. clin. Invest., 41, 743 (The fate of injected mucopolysaccharides)

Kling, D. H., Levine, M. G., AND Wise, S. (1955) Proc. Soc. exp. Biol. (N.Y.), 89, 261 (Mucopolysaccharides in tissue cultures of human and mammalian synovial membrane)

Maroudas, A., Bullough, P., Swanson, S. A. V., And Freeman, M. A. R. (1968) J. Bone Jt Surg., 50B, 166 (The permeability of articular cartilage)

RePo, R. U., AND Mitchell, N. (1971) Ibid., 53B, 541 (Collagen synthesis in mature articular cartilage of the rabbit)

SChiller, S., Slover, G. A., AND Dorfman, A. (1962) Biochim. biophys. Acta, 58, 27 (Effect of the thyroid gland on metabolism of acid mucopolysaccharides in skin)

VAes, G., AND JACQues, P. (1965) Biochem.J., 97, 380 (Studies on bone enzymes. The assay of acid hydrolases and other enzymes in bone tissue)

VAUBEL, E. (1933) J. exp. Med., 58, 85 (The form and function of synovial cells in tissue cultures. II. The production of mucin)

Yielding, K. L., Tomkins, G. M., AND Bunim, J. J. (1957) Science, 125, 1300 (Synthesis of hyaluronic acid by human tissue slices) 